\title{
SLC19A1 wt Allele
}

National Cancer Institute

\section{Source}

National Cancer Institute. SLC19A1 wt Allele. NCI Thesaurus. Code C103947.

Human SLC19A1 wild-type allele is located in the vicinity of 21q22.3 and is approximately $51 \mathrm{~kb}$ in length. This allele, which encodes folate transporter 1 protein, is involved in folic acid metabolism. 